\title{
MOOC and the Organizational Reform of Chinese Higher Education
}

\author{
Si-Yuan Ma ${ }^{1, a}$, Yin Wang ${ }^{2, b}{ }^{*}$ Wei-Jun Yang ${ }^{3, c}$ Man-Man Jiang ${ }^{4, d}$ \\ ${ }^{1}$ Faculty of Education, Beijing Normal University, Beijing, China \\ ${ }^{2}$ Faculty of Education, Beijing Normal University, Beijing, China \\ ${ }^{3}$ School of Government, Beijing Normal University, Beijing, China \\ ${ }^{4}$ School of Foreign Languages and Literature, Beijing Normal University, Beijing, China \\ amasiyuan88@163.com, bwangyin@bnu.edu.cn, cywj_1231@126.com, \\ d201211101015@bnu.edu.cn
}

* Corresponding author

Keywords: MOOC; Higher Education; Organizational Reform of Education; MOOCs; Online Education

\begin{abstract}
The Massive Open Online Course (MOOC), which refers to the rise of MOOC, has triggered the international research enthusiasm in the field of higher education. Due to the growing practical influence of MOOC, but keep away from its theoretical doctrine of Unicom, scholars not only focused on the change in curriculums, but also realized what MOOC brought to higher education which included the organizational change. Based on the analysis of the literature in recent 3 years and sorting presentations on academic conference, this study believes that massive open online course(MOOC) makes the model of educational service with internet gene gradually highlight. This kind of change will make a difference on macro-adjustment of higher education organizational system and micro-level transformation of the internal mechanism of organization in colleges and universities. At the same time, it is necessary to understand MOOC platform according to the national strategy and realizes that MOOC is a new model of online education. The study of the present situation of MOOC will help people to predict the Chinese organizational reform of higher education in future.
\end{abstract}

\section{Introduction}

The Massive Open Online Course (MOOC), which refers to the rise of MOOC, has triggered the international research enthusiasm in the field of higher education. Most scholars believe that it was the beginning of MOOC when George Simmons had a "Doctrine Unicom" course in Canadian Athabasca University in 2008. In 2011, a professor of Stanford University offered a course named "Introduction to Artificial Intelligence" online, and it attracted 1.6 million students from more than 190 countries to enroll. In 2012, three foreign MOOC platforms, Udacity, Coursera, and edX was successively established, and the year was recognized as "MOOC First Year" by New York Times [1].

During the recent four years since the MOOC appeared, the discussions about MOOC has gone through a process from frenzy to rational. Due to the growing practical influence of MOOC, but keep away from its theoretical doctrine of Unicom, Scholars not only focused on the change in curriculums, but also realized what MOOC brought to higher education which included the organizational change.

\section{The Definitions of MOOC and Organizational Change in Higher Education}

With the continuous development of MOOC, the meaning of MOOC has undergone a subtle change. In 2008, George Simmons had a MOOC course which was a practical Unicom Teaching course, and it was called "cMOOC". However, the most popular MOOC courses in the world, which is famous for its open-minded, free, and abundant resources of famous colleges and professors, is called "xMOOC". 
Besides, there are other different ideas, like SPOC, sMOOC and so on [2]. But overall, the form of xMOOC has got the widest attention.

According to Bie Dunrong who is from Huazhong University of Science and Technology, the organizational change in higher education should include "The internal organization adjustment of higher education department in macro-level, and the translation in in micro-level, showing the diversity of features." [3]

Scholars are holding positive, neutral and negative attitudes about the macro and micro influence which MOOC brought to higher education. However, according to the papers, the topic of "MOOC and Organizational Reform of Higher Education" has got wide attention even has been deeply discussed. Therefore, it is necessary to sort out the papers from recent three years. We can clear the views, think rationally by sorting, and get some suggestions for our higher education reform.

\section{The Research in MOOC and Organizational Change in Higher Education}

There is no resources about "MOOC", "Organizational Change", or "The Organizational Change of Higher Education" alone in the data base of China National Knowledge Infrastructure. However, when the authors combined "MOOC" and "Higher Education", 334 papers was founded, including 39 papers in 2013, 243papers in 2014, 52 papers in 2015, 7 master's thesis and 1 in a doctoral thesis. By reading the literature, the authors found that the domestic discussion of "MOOC and Organizational Change of Higher Education" is basically a part of the topic of "MOOC and Higher Education". The author found that these papers about organizational change in higher education involves the following three aspects according to 41 documents which has more cited quantities: First, the shift of MOOC to higher education; Second, the shift of MOOC to university management system; Third, The shift of MOOC to distance education organization. Some literatures employed the word "impact" instead of "change". This paper also discussed these three aspects.

When the author combined the word "MOOC" and "Higher Education" and searched in the Sciencedirect Datebase, they found 142 literatures. While most of the literatures are related to the MOOC impact on class, the research of organizational change is limited. Nevertheless, A few articles put more emphasis on the practice of higher education, the practical survey on online education, and give different perspectives from domestic researches.

\section{The Review of MOOC on Higher Education Reform}

The shift of MOOC to higher education teaching system. The teaching mode has transformed from going alone to collaboration. Professor Sang Xin-min of Nanjing University claims that the current university's knowledge transfer model is the product of industrial civilization and we need a efficient, student-centered lesson. Therefore, MOOC will gradually transfer traditional teaching mode to a multidisciplinary cross online class. [4]The Professor Chen Li from Beijing Normal University holds a similar view that the process of changing the individual work into team work to teachers, is just like the translation from manual workshop to industrial mass production.

Students, teachers, information services and education department will cooperate with "blended learning mode" to make changes. Ren You-qun from East China Normal University pointed out after the research of "Stanford Online" platform that "blended learning" will become a lower-cost, efficiency-improved learning method, which will determine the teaching method and the technological environment of teaching activities [5]. 
Table 1 The change of roles of students, teachers, information services and education department under the mode of class lessons combining with blended teaching model

\begin{tabular}{|c|c|c|c|c|}
\hline $\begin{array}{l}\text { Roles } \\
\text { Teaching mode }\end{array}$ & Stuc & Te & $\begin{array}{ll} & \text { Informatio } \\
\text { n } & \\
& \text { Services }\end{array}$ & Education \\
\hline $\begin{array}{l}\quad \text { The } \\
\text { educational } \\
\text { method } \\
\text { class-based } \\
\text { teaching }\end{array}$ & $\begin{array}{l}\text { 1. based on the professional } \\
\text { scheme and their assumptions to } \\
\text { select courses } \\
\text { 2. preview, attend class, and } \\
\text { review } \\
\text { 3. take the exam }\end{array}$ & $\begin{array}{l}\text { 1. prepare a lesson } \\
\text { 2. give a lesson } \\
\text { 3. homework correcting } \\
\text { 4. strengthen the learning } \\
\text { content according to the } \\
\text { homework feedback } \\
\text { 5. organize examination }\end{array}$ & none & \begin{tabular}{l}
\multicolumn{1}{c}{ Organize, } \\
formulate \\
developing \\
projects and \\
supervise the \\
executing \\
process
\end{tabular} \\
\hline $\begin{array}{l}\text { The } \\
\text { educational } \\
\text { method in the } \\
\text { combination of } \\
\text { open-class and } \\
\text { class-based } \\
\text { teaching }\end{array}$ & $\begin{array}{l}\text { 1. integrate the professional } \\
\text { scheme and the deep knowledge } \\
\text { of open-class, receiving good } \\
\text { class-selecting guide } \\
\text { 2. review the content by } \\
\text { video, attend seminar to } \\
\text { supplement the class, study with } \\
\text { teachers, friends online or by } \\
\text { face-to-face, preview the } \\
\text { knowledge by online learning } \\
\text { materials } \\
\text { 3. when necessary, students } \\
\text { can strengthen the study by } \\
\text { participating other open courses } \\
\text { 4. attend exam }\end{array}$ & $\begin{array}{l}\text { 1. develop or supplement } \\
\text { the online teaching resources } \\
2 \text {. organize seminar or } \\
\text { answer students questions in } \\
\text { class } \\
\text { 3. scan the online } \\
\text { communication forum to answer } \\
\text { students' questions } \\
\text { 4. strengthen the making of } \\
\text { online teaching resource } \\
\text { according to the feedback of } \\
\text { homework or determine a } \\
\text { seminar theme } \\
\text { 5. organize an examination }\end{array}$ & $\begin{array}{l}\text { Collaborate } \\
\text { with education } \\
\text { department to } \\
\text { plan, establish } \\
\text { and maintain the } \\
\text { open courses } \\
\text { platform }\end{array}$ & \begin{tabular}{l}
\multicolumn{2}{c}{ 1. Organize, } \\
formulate \\
developing \\
projects and \\
supervise the \\
executing \\
process \\
$\quad 2 . \quad$ plan, \\
establish and \\
manage open \\
courses platform
\end{tabular} \\
\hline
\end{tabular}

Online course and face-to-face teaching in local university mode will become a new model of teaching under the influence of MOOC [6]. Li Ming-hua noted that the current development of MOOC cannot replace the state of University, but higher education is indeed get through a full range of changes with the engulf of MOOC. With the balance between MOOC and the traditional higher education, "Online course and face-to-face teaching in local university" will become a teaching norm.

At the same time, Li Ming-hua also proposed that, the engulf of MOOC, has caused a huge impact on the credit certification institutions. She suggested that current MOOC courses are certificated by "Course platform and Course parent school", the MOOC platform will foster user's awareness of "course content are more important than university background"[6], so that have platform develop better. Next, the "non-credit certification" will go to "credit certification", while "credit certification" requires transited certification from the learner's parent university. In other words, traditional university need to correspond MOOC course's credit with their school's credit. If students learn the equivalent course content, the school should recognize it.

Different from the domestic positive attitude, the "Sloan Report" of America which is targeted in the online education, showed that the education minister who believes that the MOOC's sustainable development has decreased from $28 \%$ in $2011-2012$ to $23 \%$ in 2012-2013. Moreover, up to $64 \%$ respondents believed that the behavior that MOOC issue course certificate has led to the disorder of higher degree [8]. As a prerequisite for degree credit certification system, it is still unknown whether MOOC will be accepted or not by people.

Moreover, the Sloan Report has also reflected that online education in US is increasing steadily but the MOOC is still waiting and detecting. According to the survey of 2012-2013 school year, $15.7 \%$ of colleges and universities believe MOOC can meet all or most of the purpose, $17.2 \%$ of colleges and universities think MOOC can meet some purpose, while $85.7 \%$ of them choose "not to set up a MOOC" or "no plan to set up a MOOC". In the meantime, teachers' recognition to MOOC also made no changes. Many American researchers mention the MOOC, the appearance and spread of the H1N1 virus, the economic crisis in 2008 in the same breath. People consider that MOOC is an emergency, will affect the online education but won't bring fundamental changes to online education in the long 
term. The United States, as one of the birthplace of MOOC, takes such a conservative attitude to MOOC. This attitude itself worth China regards the online education as a whole, recognizes it has played a great role today and treated the influence of MOOC dialectically.

The Shift of MOOC to Higher Education Organizing System. Professor Xin-min Sang put forward that colleges and universities will take the management system innovation and digital transformation in public service system with the development of the MOOC [9]. Different scholars hold different opinions about the form of innovation,. Some scholar think that setting up an online system to combine colleges together, establishing the mechanism of alliance management, will be key of institutional innovation. Meanwhile, traditional universities should be familiar with the market-oriented operation to raise funds because of the huge upfront costs in the construction of network courses [10].

However, the marketization of colleges and universities will bring some problems. Li Yuan puts a question in the article. She thinks the private status of colleges and universities will trigger the controversy of the Right of Degree-conferring [11]. Nowadays, although school is the only institution which has the Right of Degree-conferring, some of the internationally renowned certification issued by information technology companies and design companies, such as the certification of Microsoft, Red Dot in German, can provide diplomas with the same satisfaction. Once the marketization reform of colleges and universities happens, enterprises will gain the power of degree awarding with the influx of money and cause a chaos in this field.

Even if higher education financial markets don't open, problems will still exist in the educational alliances, for instance, the chaos in degree awarding caused by credit certification. In addition, the education alliances will aggravate the competition among colleges and universities, cause the widening gap between the strong ones and the weak. The weak universities become classes of the strong, and experience-lacked teachers become assistants of famous teachers [12], then the universities will be ramshackle. In this way, many scholars are very cautious about the shift of MOOC to higher education organizing system.

Although the emergence of the MOOC caused problems about educational equality, scholars trust that MOOC will promote fairness of education, make higher education from popularization to mass, and force de-administration in higher education system of the colleges and universities [13], according to the concept. The realization of idea still relies on decision-making guidance. Concurrently, the appearance of MOOC makes the concept of lifelong education deeply rooted in the hearts of people, and make higher education globalization (the globalization of activities, the globalization of funds, $t$ the globalization of information) become an inevitable trend [12].

The Shift of MOOC to Distance Learning Organizing System. Organizational change of distance learning is a topic with Chinese characteristics. China's distance learning system is independent of the government management system and operational mechanism, which is different from foreign universities. Thus, the shift of MOOC to distance learning organizing system should be discussed separately.

In 2014, Professor Yong-hai Zhu put forward, "the "mode of Radio and TV university" with the influence of MOOC which means 'same platform, universities alliance, unified production and professional collaboration' .'[8] In 2015, Shao-gang Zhang, professor of Open University of China, brought forward, "the overall train of thought in Open University of China 'connected online campus, integration and change control into authorization'." Affected by the ministry of education, the Open University of China will regard curriculum culture as the core, practice the concept of lifelong learning, education rights, and equal opportunity in education. Under the influence of MOOC, China's distance learning system regards itself as a platform, and takes advantage of the policy "colleges and universities should cooperate with distance learning" to lead organization of curriculum. The solution makes the distance learning system more likes a "MOOC platform", and may solve the problem of 
"MOOC is shocking to tradition". By renewing the system of distance learning, the authority of the Open University of China can be established.

For international, "online education knowledge property right is not clear, transnational development leads to fiscal and taxpayers' boycott, damage to the interests of teachers and the legal and policy issues related to cultural differences" have become the urgent problems put forward by researchers recently[16]. Though in North America, Asia and Europe, many high quality MOOC platforms are putting online constantly, the development of MOOC is still not mature. For this reason, these sharp questions have not been point out, or in a state of pent-up so these questions are not on the agenda right now. Yet, international development is not its' short-time goal for China. Hence, the problem of financial, culture confliction which were mentioned are not crucial. Besides, under the policy of the ministry of education, the interests of teachers and intellectual property rights can be protected in a certain degree.

\section{The Enlightment of Higher Education Brought by Researches of MOOC}

The rapid development of MOOC is a huge shock to the traditional higher education. Some researchers thought that MOOC has changed the values of education, integrated science and humanity, achieved the popularization in number and elitism in finishing school, made internationalization in education platform and localization in courses [17]. Nevertheless, looking forward too much but practice too little is just the crucial problem in domestic researches. From 2012, the year of blowout in MOOC research to 2015, the influence of MOOC has been in the situation of "will be" for these four years. While the change of facts of higher education and the effect of changes were not as obvious as people concerned. In domestic researches, empirical research and data analysis were fairly limited. To change the situation, researchers need to concern more about the changes of reality. Only with the correct understanding of reality, can people make prediction more confidently.

Secondly, during the development of MOOC, people lack of the consciousness of national security. Professor Li Chen Et al. pointed out in A cold thinking in the phenomenon of MOOC tornado, "There is no free lunch in the world, the huge population in China is the main profit point of the 3 MOOC platforms in US, and the data of Chinese studying online will be the selling point of foreign companies." Therefore, it is blind to join the foreign MOOC platforms for Tsinghua university, Peking University and other colleges and universities blindly without foreseeing of the pitfalls about them. Wu-yuan Zhang also said in article, "Cooperation is not the goal, self-improvement is the end-result." However, throughout the domestic researches, the voice of establishing our own MOOC platform hasn't been paid full attention yet.

Moreover, the relationship between MOOC and online education exists a phenomenon that putting the cart before the horse. The open education today is toward the availability of learning tools and infrastructure, the availability of free and open education content and a movement face to open access to information, international collaboration and sharing of global. [18]Professor Li Chen once said, "MOOC is by no means the only model of online education". Professor Jian-gang Cheng also indicated in a conference, "It is not the MOOC created online education, but people realize the power of online education through MOOC". As a consequence, understanding the essence of the MOOC correctly, thinking about the changes, and organize courses in accordance with the principle of online education is the right way of MOOC.

Eventually, MOOC makes the model of education service with internet gene highlights gradually. MOOC do make a transformation in organizational forms, even it has not make obvious changes in teaching methods. Personalized learning supported by big data and interaction among teachers, students and learning resources on internet will be more precise, convenient and meet the needs of learners. The pattern of flattening organization, which is caused by the internet, will provide new reference for the organizational reform of Chinese higher education. 


\section{References}

[1]Y.S. Xu. MOOCs research review and enlightenment to our country's higher education. Modern Distance Education, (2014) No.3, p.8-15.

[2]X.B. Han, W.F. Zhai, and J.G. Cheng. A Dialectical Analysis of cMOOC \& xMOOC and Their Integration into the Ecological Chain of Higher Education. Modern Distance Education Research, (2013) No.6, p.3-9.

[3]D.R.Bie. Higher Education Massification and Organizational Change. Tsinghua Journal of Education, (2006) No.2, p.26-32

[4,9] X.M. Sang. Reflection on MOOCs Fervor. China Higher Education Research, (2014) No.6, p.5-10.

[5]Y.Q. Ren, S.M. Xu. The Exploration of and Reflection upon Open Courseware: From Learners, Decision - Makers to Constructors. Modern Distance Education Research, (2013) No.5, p.3-10.

[6,7] M.H. Li. MOOCs Revolution: The Emergence of Independent Course Markets and the New World Higher Education Market Structures, Open Education Research, (2013) No.3, p.11-29.

[8]Y.H. Zhu, X.B. Han, and J. Yang. Irreversible Online Development of Higher Education: Systematic Analysis of 11-Year Sloan Consortium Report Series on Online Education in the US. Tsinghua Journal of Education, (2014) No.4, p.92-100.

[10]X.S. Zhai, J. Yuan. The difficulties and countermeasures of MOOC in our country's higher education development Network Education and Remote Education, (2014) No.10, p.97-102.

[11] L. Yuan, Stephen Powell. The Impact of MOOCs on Higher Education: A Perspective from Theory of Disruptive Innovation. Modern Distance Education Research, (2014) No.2, p.3-9.

[12] Y.S. Xu. MOOCs research review and enlightenment to our country's higher education. Modern Distance Education, (2014) No.3, p.8-15.

[13]Z.W. Zhang. The MOOCs and Chinese higher education. Journal of Hebei Normal University, (2014) No.2, p.116-121.

[16] J.P. Wu, K. Zhao. On Policy Choice of MOOCs. Tsinghua Journal of Education, (2013) No.4, p.1-5.

[17] H.H. Liu, Q.B. Li, and S.Y. Zhang Impact of MOOCs on Higher Education - Based on Core Value of Higher Education, (2014) No.4, p.517-521

[18] Curtis.J. Bunker: The World Is Open: How Web Technology Is Revolutionizing Education (East China Normal University Press, China 2009), p.44-55 